\title{
WORKSHOP GURU MATEMATIKA MENGGUNAKAN WORD PROCESSOR FORMULA DAN PENGELOLAAN KELAS
}

\author{
Selamet Riyadi ${ }^{1}$, Tri Candra Wulandari ${ }^{2}$ \\ ${ }^{1,2}$ Pendidikan Matematika, ${ }^{1,2}$ Fakultas Sains dan Teknologi, \\ ${ }^{1,2}$ Universitas Kanjuruhan Malang \\ 1,2 selametriyadi@unikama.ac.id
}

\begin{abstract}
ABSTRAK
SMP Sunan Kalijogo merupakan salah satu sekolah mengenag pertama di Kecamatan Jabung Kabupaten Malang yang berbaisis pondok pesantren. Mayoritas siswa di sekolah tersebut bersumber dari pondok pesantren Sunan Kalijogo meskipun ada juga siswa yang tidak mondok tepi hanya sebagian kecil saja. Dengan realitas sepeti itu dan ditambah dengan padatnya kegiatan di pondok pesantren menyebabkan siswa kurang antusias untuk belajar di sekolah. Sehingga tidak jarang guru mengeluh kurang bisa mengendalikan kelas yang sedang diajarnya. Karena banyak siswa yang mengantuk ketika pelajaran di kelas dan ada juga siswa yang bercanda dengan teman di dekatnya ketika guru menjelaskan. Untuk mengatasi hal tersebut dan untuk menambah kondusifitas pembelajaran maka tim pengabdian kepada masyarakat Universitas Kanjuruhan Malang mengadakan pelatihan menggunakan Word Prosesor Formula dan beberapa pendekatan pembelajaran yang sesuai dengan kondisi sekolah tersebut dan berbasis kurikulum 2013. Beberapa pendekatan pembelajaran yang disampaikan yaitu Inquiry Based Learning (IBL) dan Problem Based Learning (PBL). Tujuan dari kegiatan ini yaitu untuk meningkatkan keterampilan menggunakan Word Prosesor Formula serta menambah pengetahuan guru-guru tentang pembelajaran kurikulum 2013 yang sesuai dengan kondisi sekolah tersebut. Dengan harapan pengetahuan tersebut bisa digunakan untuk meningkatkan kondusifitas pembelajaran di SMP Sunan Kalijogo. Metode yang digunakan dalam kegiatan ini yaitu pelatihan dan pendampingan. Hasil yang diperoleh yaitu guru-guru mempunyai pengetahuan dan keterampilan yang baik dalam pengelolaan kelas sehingga pembelajaran menjadi kondusif.
\end{abstract}

Kata-kata kunci : kondusifitas pembelajaran, pengeloloaan kelas, pondok pesantren

\section{PENDAHULUAN}

SMP Sunan Kalijogo merupakan salah satu sekolah menengah pertama yang berada di bawah naungan Yayasan Sunan Kalijogo Jabung. Sekolah ini berbasis pondok pesantren meskipun tetap menerima siswa-siswa dari luar pondok pesantren tersebut. Sehingga siswa dan siswa di sekolah tersebut ada yang menetap di pondok pesantren dan ada pula yang tidak.
Secara fisik, sarana dan prasarana di SMP Sunan Kalijogo cukup memadai untuk melaksanakan kegiatan belajar mengajar. Mulai dari ruang kelas yang terlihat bersih, laboratorium, perpustakaan, sampai lapangan olah raga, sudah tersedia di sekolah tersebut. Kegiatan belajar mengajar pun telah berjalan sesuai jadwal yang berlaku. Dengan kata lain, guru-guru dan semua sumber daya manusia yang ada telah melaksanakan tugasnya dengan cukup disiplin. Hanya saja dalam proses pembelajaran, guruguru kurang menguasai kelas. Sehingga 
banyak peserta didik yang kurang memperhatikan guru, bicara sendiri, dan bercanda dengan teman di dekatnya. Bahkan karena banyaknya kegiatan di pondok sehingga tidak jarang siswa yang ngantuk dan tidur ketika di kelas.

Oleh karena itu guru-guru di SMP Sunan Kalijogo Jabung merasa perlu untuk mengetahui lebih banyak tentang penggunaan Word Prosesor Formula teknik-teknik pengelolaan kelas. Karena kurikulum yang digunakan adalah Kurikulum 2013 sehingga perlu dibekali keterampilan menggunakan Word Prosessor Formula dan teknik pengelolaan kelas yang berbasis pada pembelaran K13.

Teknik pengelolaan kelas tidak lepas dari pendekatan pembelajaran yang digunakan. Jika pendekatan pembelajaran yang digunakan ini dilaksanakan dengan pengelolaan dan penyesuaian yang baik, maka pendekatan tersebut bisa menjadi solusi terbaik dalam mengkondisikan siswa di kelas. Pendekatan pembelajaran yang dirasa cocok untuk diterapkan dalam kurikulum 2013 dan permasalahanpermasalahan di atas yaitu Inquiry Based Learning (IBL) dan Problem Based Learning (PBL).

Pendekatan IBL merupakan suatu pendekatan yang yang digunakan dan mengacu pada suatu cara untuk mempertanyakan, mencari pengetahuan (informasi), atau mempelajari suatu gejala. Inkuiri yang berarti pertanyaan atau pemeriksaan dan penyelidikan (Gulo, 2005). Dari pengertian tersebut, IBL merupakan suatu pendekatan pembelajaran yang mampu melibatkan siswa langsung ke dalam kehidupan nyata dengan melakukan penyelidikan sendiri terhadap makna dan tujuan dari suatu materi pembelajaran.

PBL menekankan pada pemecahan masalah, menyadari kebutuhan akan pengajaran dan pembelajaran yang terjadi dalam berbagai konteks seperti di rumah, pekerjaan, dan masyarakat. Tahap-tahap pendekatan PBL menurut (Pratiwi, 2010) yaitu (1) orientasi siswa pada masalah, (2) mengorganisasi siswa untuk belajar, (3) membimbing penyelidikan individual, (4) membimbing analisis data, (5) membimbing, membangun dan menyajikan hasil karya, dan (6) menganalisis dan mengevaluasi proses pemecahan masalah.

Dengan pembelajaran IBL dan PBL siswa akan melakukan interaksi dengan siswa lain, guru, dan lingkungan sekitar siswa belajar. Sehingga pembelajaran ini akan menghasilkan siswa yang berkarakter dan juga akan meningkatkan kondusifitas pembelajaran.

\section{METODE KEGIATAN}

Kegiatan pengabdian ini dilaksankan dalam bentuk suatu pelatihan yang dilaksanakan selama sehari penuh, mulai jam 08.00 WIB sampai jam 15.00 WIB dengan peserta sebanyak 30 orang guru. Kegiatan ini dilaksanakan di SMP Sunan Kalijogo Jabung Malang. Sesi pertama membaas tentang Calssrom Management dan beberapa pendekatan pembelajaran yang cocok digunakan pada kurikulum 2013. Salah satu yang dibahas yaitu Inquary Based Learning (IBL) dan Problem Based Learning (PBL) termasuk langkah-langkah, kekurangan dan kelebihannya. Sesi kedua diisi dengan pendalaman materi dan simulasi penerapan IBL dan PBL dalam pembelajaran. 
Adapun langkah-langkah pelaksanaan kegiatan adalah sebagai berikut:

\section{Persiapan}

a. Tim pengabdian mengurus surat ijin dan surat tugas untuk melaksanakan kegiatan pengabdian kepada masyarakat.

b. Menghubungi kepala SMP Sunan Kalijogo Kecamatan Jabung untuk menetapkan jumlah peserta dan jadwal pelaksanaan pengabdian kepada masyarakat.

\section{Pelaksanaan}

a. Pelatihan menggunakan Word Prosesor Formula dan Pengelolaan Kelas

Tim pengabdian masyarakat membahas secara garis bersar kurikulum 2013. Seperti karakter dan keterampilan 4C's (Critical tingking, Creative thinking, collaborative, dan communicative skill) yang harus dimiliki siswa. Selanjutnya diberikan pengetahuan tentang pengelolaan kelas dan metode pembelajaran yang berbasis kurikulum 2013 revisi yaitu IBL dan PBL.

\section{b. Pendampingan}

Tim pengabdian masyarakat memberikan arahan dan pendampingan kepada guru dalam melakukan praktek atau simulasi penerapan IBL dan PBL dalam pembelajaran.

\section{KARYA UTAMA}

Kegiatan pengabdian ini dilaksanakan memberikan pelatihan tentang pengeloloan kelas berbasis pembelajaran kurikulum 2013. Khusunya diberikan pengetahuan tentang pendekatan pembe- lajaran IBL dan PBL.

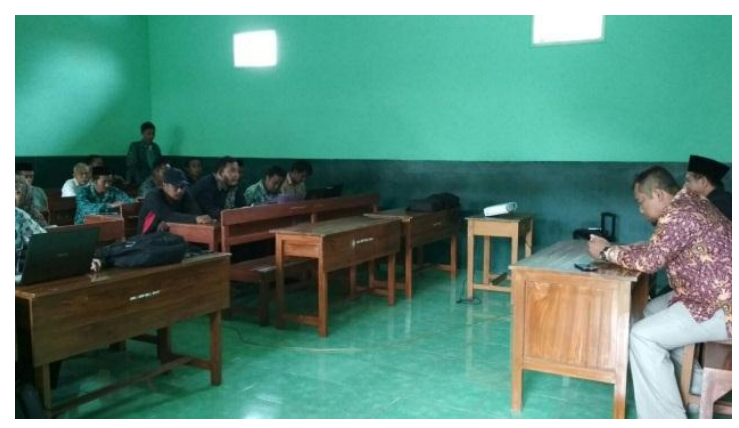

Gambar 1. Pembukaan Acara

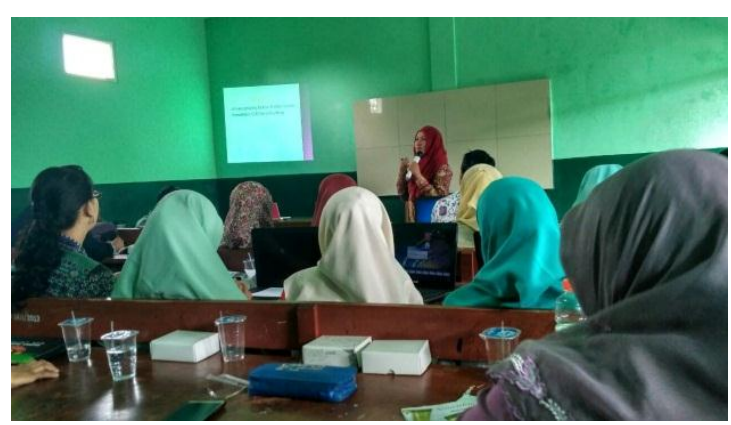

Gambar 2. Pemberian Materi Word Prosesor Formula Pengelolaan Kelas

Selanjutnya pada kegiatan pengabdian ini dilakukan pendampingan pada saat simulasi atau praktek penerapan IBL dan PBL dalam pembelajaran.

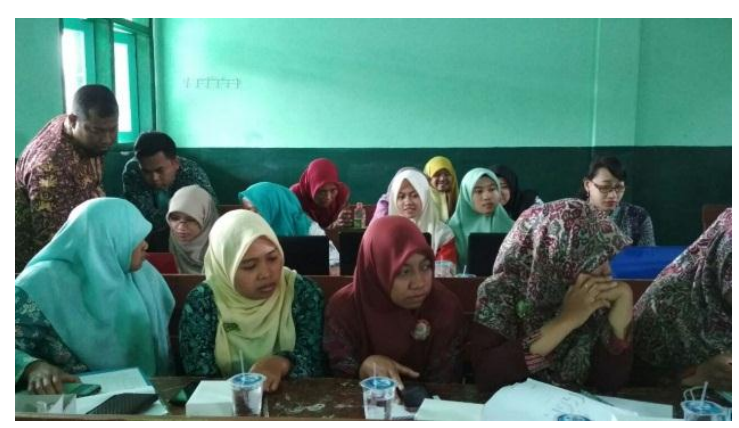

Gambar 3.Pendampingan Simulasi

\section{ULASAN KARYA}

Kegiatan pengabdian kepda masyarakat ini dilaksanakan selama sehari yang terdiri dari dua sesi. Sesi pertama pemberian materi tentang keterampilan menggunakan Word Prosesor Formula dan teknik-teknik 
pengelolaan kelas yang berbasis pembelajaran kurikulum 2013. Dalam hal ini diberikan pengetahuan tentang pendekatan pembelajaran Inquriy Based Learning (IBL) dan Problem Based Learning (PBL). Selain itu dalam pelatihan juga ditambahkan pengetahuan tentang komponen 4C's (Critical thinking, Creative thinking, Colaborative, and Comunative Skills) yang harus ditekankan dalam pembelajaran kurikulum 2013.

Berdasarkan pengamatan selama kegiatan pengabdian kepada masyarakat berlangsung, diperoleh beberapa hasil yang baik yaitu diantaranya:

1. Semua peserta pelatihan dalam kegiatan pengabdian ini menunjukkan sikap yang positif dan menunjukkan perhatian yang sangat tinggi terhadap materi yang disampaikan oleh tim pengabdian.

2. Para peserta menunjukkan reaksi yang positif terhadap cara menerapkan pendekatan pembelajaran IBL dan PBL.

3. Para peserta memiliki keingintahuan yang lebih tentang materi yang disampaikan. Hal itu terlihat dari bayaknya peserta yang aktif bertanya dan mengungkapkan masalahmasalah yang dialaminya selama mereka mengajar dan mereka bersemangat untuk dapat menerapkan pendekatan IBL dan PBL ini dalam mengajar.

4. Para peserta terlihat kompak dan menjalin kerja sama yang cukup baik selama praktek dan simulasi pembelajaran IBL dan PBL.

Para peserta pengadian ini, yaitu guru-guru di SMP Sunan Kalijogo
Jabung memperoleh banyak pengetahuan dan keterampilan yang berkaitan dengan pengelolaan kelas dengan pembelajaran berbasis kurikulum 2013. Sebaliknya bagi tim pengabdian kepada masyarakat, tim pengabdian memperoleh masukan yang bermanfaat tentang masalahmasalah dan kendala yang dialami guruguru SMP Sunan Kalijogo selama mereka melaksanakan pembelajaran di sekolah, terutama dalam hal pemilihan pendekatan pembelajaran. Semua pengalaman tersebut dapat digunakan sebagai bahan pertimbangan untuk melaksanakan pengabdian kepada masyarakat berikutnya.

Kegiatan pengabdian kepada masyarakat ini secara umum berjalan dengan lancar dan tanpa kendala yang berarti. Hanya saja karena keterbatasan dana untuk pelaksanaan pengabdian ini, maka menyebabkan keterbatasan bentuk, jenis, dan waktu pelaksanaan kegiatan.

\section{DAMPAK DAN MANFAAT KEGIATAN}

Dampak dan manfaat dari kegiatan pengabdian kepada masyarakat di SMP Sunan Kalijogo Jabung ini yaitu: (1) guruguru SMP Sunan Jalijogo Jabung memperoleh pengetahuan tentang pendekatan pembelajaran yang cocok untuk kondisi sekolah dan berbasis kurikulum 2013, (2) guru-guru SMP Sunan Kalijogo mengetahui secara praktis tentang penerapan pendekatan pembelaran IBL, (3) memperoleh pengetahuan praktis tentang penerapan pembelaran PBL, dan (4) menambah kondusifitas pembelajaran di SMP Sunan Kalijogo melalui pemilihan pendekatan pembelajaran yang tepat untuk kondisi sekolah tersebut. 


\section{KESIMPULAN}

Kesimpulan yang diambil dari kegiatan pengabdian kepada masyarakat ini, berdasarkan uraian yang telah disampaikan sebelumnya yaitu kegiatan pengabdian kepada masyarakat ini dapat:

1. Meningkatkan pengetahuan dan keterampilan guru-guru SMP Sunan Kalijogo Jabung Kabupaten Malang dalam memilih pendekatan pembelajaran untuk meningkatkan kondusifitas pembelajaran di kelas.

2. Meningkatkan semangat guru-guru di SMP Sunan Kalijogo Jabung Kab. Malang untuk memberikan pelayanan dan kualitas pembelajaran yang terbaik untuk siswa-siswnya.

\section{PENGHARGAAN}

Penghargaan yang sebesar-besarnya dan ucapan terima kasih disampaikan kepada LPPM Universitas Kanjuruhan Malang, Kepada SMP Sunan Kalijogo, dan seluruh guru SMP Sunan Kalijogo Jabung yang telah ikut berpartisipasi dalam kegiatan pengabdian kepada masyarakat ini sehingga kegiatan ini dapat berjalan dengan lancar dan selesai tepat waktu.

\section{DAFTAR PUSTAKA}

[1] Anonim (1992), Kamus Besar BahasaIndonesia. Bandung: Balai Pustaka.

[2] Dasna, I Wayan dan Sutrisno. Pembelajaran Berbasis Masalah. Jurusan KIMIA F-MIPA Universitas Negeri Malang.

[3] Permana, Johar, "Pengelolaan Kelas dalam Rangka Proses Belajar
Mengajar" disajikan pada TOT Nasional Pelatihan Supervisi Pendidikan Madrasah Ibtidaiyah dan Tsanawaiyah Basic Education Project (BEP), 2001.

[4] Pratiwi, Dwi Astuti. "Pembelajaran Berbasisi Masalah (Problrm Based Learning ) dengan Metode Proyek dan Resitasi Ditinjau dari Kreativitas dan Konsep Diri (Self Consep) Siswa" Thesis, Universitas Sebelas Maret, 2010. 